\title{
pro.posıções
}

\section{Literatura para a infância no jardim de infância: contributos para o desenvolvimento da criança em idade pré-escolar}

\section{Children's literature in the kindergaten: contributions to the development of the child at pre-school age}

\begin{abstract}
Resumo
Pretende-se, no presente artigo, demonstrar que, nos livros para crianças, a relação dialogal e a fusão intersemiótica entre as linguagens verbal e icónica potenciam a instauração de uma atmosfera poética imprescindível na formação estético-literária da criança pré-leitora, que, no processo hermenêutico de apropriação e construção de sentidos, sozinha ou pela mão do adulto-mediador, se assume como um ser cognoscente e cocriador do universo textual, encetando um percurso enunciativo de intensa cooperação interpretativa. Pretende-se igualmente problematizar o lugar dos livros no jardim de infância e o seu contributo para o desenvolvimento cognitivo, social e emocional da criança em idade pré-escolar, atribuindo pedagogicamente ao adulto-mediador um papel determinante nesse processo de construção do ser em crescimento nomeadamente através do recurso ao livro de qualidade estética e literária.

Palavras-chave: literatura para a infância, educação pré-escolar, formação estéticoliterária, desenvolvimento infantil.
\end{abstract}




\section{pro.posıções}

Abstract
It is intended in this article to demonstrate that in children's books, the dialogical
relationship and intersemiotic fusion between verbal and iconic languages create a
poetic atmosphere of real meaning that seems indispensable in aesthetic-literary
formation of the pre-reading child. In fact, in the hermeneutical process of
appropriation and construction of meanings, alone or by the hand of an adult-
mediator, the child is a co-creator of the textual universe, engaging an enunciative
journey of intense interpretative cooperation. It is also intended in this article to
question the place of books in the kindergaten and their contribution to the
cognitive, social and emotional development of children in preschool age, giving to
the adult-mediator a decisive role in this construction process particularly through
the use books of aesthetic and literary quality.
Keywords: literature for children, pre-school education, aesthetic and literary
education, child development.

\section{Literacia emergente e literatura infantil no jardim de infância: o papel do adulto-mediador}

É hoje consensual que as crianças em idade pré-escolar, quando inseridas em ambientes educativos ricos em experiências de literacia, contactando com diversos suportes e materiais de escrita, "desenvolvem diferentes conhecimentos sobre a linguagem escrita, mesmo antes de, formalmente, estes lhes serem ensinados" (Mata, 2008, p.9). Com efeito, as investigações que têm vindo a ser desenvolvidas nesta área demonstram que, quanto mais precoce e sistemático for o contacto com o mundo do impresso, mais facilmente as crianças se apropriam das convenções do código escrito, desenvolvendo conceções sobre as funcionalidades e os aspetos figurativos e conceptuais da linguagem escrita, as estratégias e os comportamentos de leitor, procurando, de forma espontânea, ensaiar as suas primeiras tentativas de leitura e escrita, que naturalmente um educador responsivo deve incentivar e valorizar.

Essas conceções precoces sobre a linguagem escrita, que as crianças vão adquirindo desde tenra idade, decorrem, como afirma Mata (2008), do facto de 


\section{pro.posições}

as crianças interagirem, mesmo em contextos informais, com outras crianças e adultos que utilizam a escrita, e de serem aprendizes activos, que constroem conhecimentos sobre o mundo, à medida que exploram o meio envolvente e reflectem sobre as suas explorações. As interacções com a escrita, mediadas por adultos e outras crianças, têm um grande impacto no desenvolvimento das concepções e dos conhecimentos de que as crianças se apropriam sobre a linguagem escrita. (p.9)

Naturalmente que, quanto mais frequentes forem as interações com a leitura e a escrita em contextos educativos promotores de uma literacia emergente, quanto mais a leitura e a escrita fizerem parte do quotidiano da criança, mais facilmente as crianças desenvolverão os seus projetos pessoais de leitores e escritores envolvidos e comprometidos com a linguagem.

Assim se compreende que o adulto deve criar contextos educativos que promovam e facilitem o contacto com diversos suportes de leitura - revistas, jornais, livros de diversa tipologia - e deixar as crianças manusearem livremente esses materiais diversificados, de modo a estimular a sua curiosidade sobre o impresso. Mas deve fazê-lo igualmente de forma consciente e com intencionalidade pedagógica, criando "oportunidades para as crianças explorarem atividades e acontecimentos de literacia, inserindo-as nas atividades do quotidiano numa perspetiva curricular transversal e global" (Marchão, 2013, p.30), recorrendo para tal a estratégias que, não tendo obviamente como intuito escolarizar o processo de aquisição das conceções infantis sobre o código escrito (e o visual), auxiliem as crianças a envolverem-se ativamente e de forma significativa e contextualizada no processo de descoberta da escrita.

Nesse ambiente educativo potenciador de aprendizagens significativas, os livros ocupam, naturalmente, um lugar de destaque. Sabemos que, na primeira infância, os livros mais indicados são os livros-brinquedo, os pop-up, os álbuns, os livros com formas, texturas, cores e sonoridades que permitem estimular os cinco sentidos e que despertam emoções e o prazer da descoberta, mas o certo é que, à medida que crescem, as crianças se vão deixando seduzir por outro tipo de livros. Na verdade, o contacto com uma grande diversidade de obras que o adultomediador deve colocar à disposição das crianças, contribui não só para a aquisição da literacia, como defende Azevedo (2003), mas também para o desenvolvimento de competências cognitivas, linguísticas, estéticas, socioafetivas e emocionais.

Os livros de qualidade estética e literária detêm uma importância fundamental não só para estimular a fruição e a compreensão leitora, mas também para potenciar aprendizagens significativas, devendo o educador agir pedagogicamente e de forma responsiva às necessidades e aos interesses das crianças. Nesse contexto se percebe que a literatura infantil, enquanto 


\section{pro.posıções}

ISSN 1980-6248

fenómeno estético e literário de inestimável valor, poderá instituir-se como um recurso pedagógico essencial para estimular a reflexão e o espírito crítico da criança em relação a si própria e ao mundo que a rodeia.

Esses livros, com os quais a criança deve ter contacto o mais precocemente possível, permitirão ir desenvolvendo a sensibilidade estética, o espírito crítico, o pensamento divergente e a educação emocional dos mais novos. A este propósito refere Lopes (2012) que, em contacto com os livros de qualidade,

a criança lê, imagina, sonha, sente, emociona-se - à beira da ira e do compadecimento absoluto -, aprende e, por fim, espelha esse aprendizado em seu próprio mundo. Por esse motivo, os livros infantis são ... nascedouros da experiência estética, que é a base de toda a cognição humana. (p. 110)

Um educador empenhado em desenvolver essas (e outras, naturalmente) competências nas crianças que tem à sua guarda deve selecionar criteriosamente os livros que lhes oferece ao olhar, porque a ele, educador e adulto-mediador, compete apresentar livros que surpreendam, que provoquem deslumbramento, que emocionem e façam sonhar, que alarguem a capacidade imaginativa e reflexiva do recetor infantil, que estimulem a sua sensibilidade artística e lhe permitam apurar o gosto, porque, como refere Veloso (2005), o gosto da criança “ainda não existe de forma sustentada, tendo em conta as reduzidas vivências e o limitado conhecimento experiencial que alimentam um espírito crítico ainda em formação” (p.2).

Defendemos que o adulto-mediador não deve ignorar (e tampouco menosprezar) os gostos e os interesses de leitura das crianças, sob pena de estar a comprometer o seu futuro de leitores apaixonados e envolvidos com os livros e com o universo da leitura, mas não pode demitir-se da sua missão educativa que, nesse contexto, passa por lhes dar a ler livros de qualidade estética e literária - livros que alimentam a imaginação e a sensibilidade das crianças e permitem estimular o gosto pela leitura (ou pela audição da leitura em contexto pré-escolar); livros que emocionam e deslumbram pelo poder encantatório das palavras e das ilustrações; livros que desafiam a ver o mundo com os olhos da fantasia e a aventurar-se pelos caminhos da ficção; livros que potenciam simultaneamente o desenvolvimento cognitivo, socioafetivo e emocional das crianças, se devidamente abordados em contexto educativo pelo educador de infância. 


\section{pro.posıções}

Falamos, naturalmente, de literatura para a infância, esse "lugar de afetos, onde as palavras, usadas de forma poética e plurissignificativa, são frequentemente emolduradas de silêncios eloquentes, estimulando a capacidade inferencial da criança" (Mendes, 2013, p.36). Falamos desse "lugar" tão específico e tão especial que alicia e emociona não apenas a criança; um lugar onde também os adultos se encontram e reencontram, sempre com o mesmo olhar fascinado da inocência e da infância entretanto perdida, mas pela Literatura reconquistada.

É justamente da literatura para a infância, das suas especificidades e potencialidades, da sua relevância e do seu contributo para o desenvolvimento cognitivo, psicológico, socioafetivo e emocional da criança que falaremos em seguida, alicerçando o nosso pensamento na teoria e na crítica literárias e nas investigações científicas recentemente realizadas, que equacionam e problematizam o papel da literatura para a infância no desenvolvimento infantil e em particular em contexto pré-escolar.

\section{Especificidades e potencialidades da literatura para a infância em contexto pré-escolar: a fecundidade do diálogo intersemiótico}

Tal como tem vindo a ser assumido pela teoria e pela crítica literárias desde os anos 90 do século XX (Cervera, 1992; Hunt, 1994, entre outros), no vasto universo dos livros para crianças nem todos se inserem no subsistema literário e intersemiótico infantil. Nesse sentido, importa perceber em que consiste a literatura para a infância e em que medida este subsistema literário se distingue dos restantes livros destinados a crianças. $\mathrm{Na}$ verdade, várias definições têm sido sugeridas nas últimas décadas, sendo que a proposta por Juan Cervera, em 1992, nos parece ser ainda o pressuposto que constitui a base estruturante neste domínio. Assim, para o autor de Teoria de la literatura infantil, neste subsistema se inclui toda a produção que tem como veículo a palavra com um toque artístico ou criativo e, como destinatário, a criança (Cervera, 1992, p. 11). Antes e depois de Cervera, outros estudiosos aludiram (e aludem) a essa dupla dimensão da literatura preferencialmente destinada ao público infantil - o seu valor artístico e a existência de uma instância recetiva preferencial, mas não exclusivamente infantil (Cerrillo, 2001; Padrino, 2001). 


\section{pro.posições}

ISSN 1980-6248

A dimensão artística da linguagem é, contudo, o que distingue este subsistema literário dos restantes livros para o potencial recetor infantil. Com efeito, existem no mercado inúmeros livros que não podem, na perspetiva de Mergulhão (2008), “ser entendidos como literários porque lhes falta a dimensão imaginante e a linguagem poético-simbólica e conotativa que caracteriza o texto literário” (p.45). Efetivamente parece não haver dúvidas entre os estudiosos a esse respeito. Cerrillo (2001) sintetiza dessa forma o pensamento de autores como Cervera (2001), Hunt (1994), Padrinho (2001), entre outros:

La Literatura Infantil es, ante de todo y sobre todo, literatura, sin - en principio - adjetivos de ningún tipo; si se le añade "infantil" nos es sino por el deseo de delimitar una época concreta de la vida del hombre que, en literatura, está marcada por las capacidades de los destinatarios lectores, y, en menor medida, por gustos e intereses lectores muy concretos. (p.87)

O maior problema consiste em perceber o que é ou não literário num livro para crianças, sobretudo quando se trata de álbuns narrativos em que a imagem é predominante e se sobrepõe ao texto verbal. Se a fronteira entre o literário e o não literário nesses casos é muito ténue, e apesar da dimensão reduzida do texto, o certo é que

existem álbuns narrativos onde essa qualidade [literária] é evidente, por se socorrerem de mecanismos discursivos ou narrativos (como a adjectivação expressiva, a adopção de diferentes pontos de vista e de diferentes modos de expressão literária) e procedimentos estilísticos (como as anáforas, as aliterações, as enumerações em assíndeto ou polissíndeto, as comparações, as metáforas, as personificações, e tantos outros), que permitem ao pequeno leitor um primeiro contacto com as convenções do discurso literário. (Mergulhão, 2008, p. 47)

Defendemos, como Azevedo (2003) e Mergulhão (2008), que os livros de qualidade estética e literária destinados à primeira infância se socorrem de recursos expressivos e procedimentos técnico-literários que as crianças, mesmo não possuindo ainda a sua competência literácita completamente adquirida devido à sua curta experiência de vida, conseguem entender, interiorizando (embora por vezes de forma inconsciente) os sentidos implícitos que tais procedimentos estético-literários veiculam. Azevedo (2003) defende, aliás, esse contacto precoce com obras de grande riqueza e densidade semântica para elevar a competência literácita da criança, afirmando que "é precisamente nesta dimensão de contacto com formas mais complexas e mais elaboradas da língua que nos parece extremamente útil a familiarização precoce da criança com textos de qualidade literária” (p. 2). 


\section{pro-posıções}

ISSN 1980-6248

Entendemos também que tais livros, por aliarem texto e imagens através de processos intersemióticos de grande produtividade semântica, não só estimulam o prazer da leitura como desenvolvem a sensibilidade artística dos mais jovens, estabelecendo desde cedo uma ligação afetiva e um forte impacto emocional com o livro objeto artístico. Assim se compreendem (e se corroboram) as palavras de Veloso (2005), que defende que "o livro para crianças, precisamente porque é para crianças, tem de ser uma obra de arte" (p.9). De facto, no livro para crianças devem conviver, de forma harmoniosa e esteticamente congruente, o texto verbal e o texto visual, ambos detentores de qualidades artísticas "que alarguem a competência interpretativa do jovem (pré)leitor e que lhe permitam educar a sensibilidade o mais precocemente possível" (Mergulhão, 2008, p.54).

Aliás, a articulação intersemiótica entre texto e imagem nos livros para crianças tem merecido um crescente interesse por parte da teoria e da crítica literárias (e do público em geral), sendo hoje consensual que essas duas linguagens artísticas se intersecionam e se complementam entre si de forma a tornar o livro para crianças uma obra de arte e um artefacto cultural com múltiplas possibilidades de leitura, devido à plurissignificação presente no texto e nas imagens.

Com efeito, quanto mais plurissignificativos forem os textos literários, mais margem deixam para o preenchimento dos espaços em branco que o potencial leitor infantil conseguirá, sozinho, ou pela intervenção do adulto-mediador, completar. Da mesma forma, quanto mais polissémicas forem as ilustrações, maiores possibilidades terá a criança de libertar a sua imaginação e ir construindo mundos alternativos, penetrando na estrutura simbólica e imagética com um olhar cada vez mais pormenorizado e focalizado, atribuindo, dessa forma, novos significados à narrativa visual e, consequentemente, à obra no seu conjunto, porque só a articulação intersemiótica entre o texto verbal e o pictórico confere ao livro a sua unidade de sentido (ainda que esta possa variar de leitor para leitor, devido, precisamente à polissemia de que a obra literária se reveste).

Especificamente no caso dos álbuns narrativos para a infância, a ilustração é um elemento preponderante, por facilitar a compreensão do texto verbal e dos sentidos que, de forma explícita ou implícita, ele transmite e veicula, uma vez que "sua carga afectiva é de longe mais forte do que a do texto, porquanto vai até ao universo inconsciente da criança e constitui uma aprendizagem e uma emoção vital" (Soares, 1994, p. 246). Ao encontrar-se com o livro, a criança pré-leitora (e provavelmente todas as crianças leitoras, independentemente do estádio 


\section{pro.posições}

de desenvolvimento e do nível de desempenho na leitura em que se encontram) é atraída de imediato pelas ilustrações, porque são elas que se instituem como "factor promotor de (des)gosto em face do objecto-livro" (Silva, 2003, p. 1) e são elas que produzem desde logo significado(s).

É percorrendo, maravilhada, as páginas ilustradas que a criança vai construindo a sua narrativa, por vezes fazendo-o em voz alta, para si ou para os outros. Essa forma de ler é uma das primeiras manifestações da literacia visual da criança. Ela descobre, com os seus olhos virginais de espanto, pormenores que escapam ao olhar desatento e apressado do adulto. Mais: ela consegue ver para além do visível, porque a ilustração, mais do que ser da ordem do visível, é da ordem do inefável. Sabemos que a leitura das imagens antecede a leitura do texto verbal. Já Soares (1994) defendia que

a criança desde muito cedo é um "homo imageticus". Ela começa por ver imagens, antes mesmo de se exprimir verbalmente. Ela vive num universo em que a imagem está omnipresente e é dotada de uma carga atractiva tão forte, tão interpelante, tão apelativa que a leitura pictórica, antecede logicamente a leitura verbal. É que a imagem fala, significa, e é ponto de partida para o imaginário. (p.242)

Assim se percebe que, muito antes de saber ler, a criança dá asas à sua imaginação, explorando e lendo à sua maneira as imagens presentes nos livros, inventando desse modo as histórias que a narrativa visual lhe sugere. Como sublinha Mergulhão (2008),

Num processo fascinante de contínua descoberta, a criança vai-se apropriando afectivamente do objecto que tem em seu poder, folheando as páginas e construindo, com a sua particular forma de ver e de sentir, um percurso imaginativo muito próprio, a partir das ilustrações e dos elementos compositivos que configuram a narrativa visual. (p.50)

Ou seja, apesar de a ilustração normalmente surgir a posteriori, para dar cor e vida ao texto verbal que é suposto precedê-la (o que, aliás, nem sempre acontece), a verdade é que muitas vezes é a ilustração que suplanta o texto, que o ultrapassa, que o asfixia, de certa forma, na medida em que a criança que já leu as imagens provavelmente sentirá uma certa frustração ao ouvir ler o texto, porque esse texto que ouve ler já não é o texto que ela criou mentalmente enquanto observava as imagens. Tal pode acontecer porque, como defende Miguel Angel Guerra (citado por Soares, 1994, p.246), "a ilustração dirige-se em primeiro lugar à sensibilidade e só depois à mente, enquanto que a palavra parece percorrer o caminho inverso" A este propósito refere Soares (1994) que 


\section{pro.posições}

a polissemia da imagem é inquestionavelmente maior do que a da palavra, ou seja, a ilustração é dotada de fortes marcas conotativas, na medida em que tem em si enormes potencialidades genésicas ao nível da evocação, da imaginação, do ludismo, da estesia. (p. 246)

Contudo, e como as investigações realizadas por Maia (2002), Nikolajeva e Scott (2001), Nodelman (1988), Sipe (2007), entre outros autores, o demonstram, defendemos que é precisamente o encontro dessas duas linguagens que enriquece a criança, na medida em que a leitura é sentida como um jogo e um desafio de interpretação: "a ilustração introduz o espanto na leitura” (Maia, 2002, p.3), "obrigando" a criança a deter-se ora no texto, ora nas imagens, e a perceber as relações de sentido que se estabelecem entre si. Essa relação de interdependência entre os dois códigos é que atribui verdadeiramente ao álbum para crianças a sua singularidade, pois só é possível compreendê-lo na plenitude através da leitura dos dois discursos.

Acresce-se que, apesar de ser inegável o poder da imagem, ela não pode, não deve sufocar o texto, nem deve deixar-se suplantar por ele. Trata-se, deve tratar-se, de uma relação de equilíbrio e simbiose, em que as duas linguagens coexistem e se intersecionam para alimentar no leitor a fruição e a emoção estética, e também a compreensão da leitura. A ilustração deve, pois, ser entendida como uma interpretação do texto e não como uma mera "tradução ou explicação do legível [porque] ela não lida com o legível mas com o invisível, com aquilo que se esconde atrás das linhas do texto e permanentemente se oferece e escapa aos sentidos" (Maia, 2002, p. 3). Tal significa que o ilustrador consegue captar os sentidos que o autor propositadamente deixou em aberto para que o circuito comunicativo (literário) se completasse e o seu texto ganhasse outras formas e, sobretudo, outros sentidos.

Ora, esse trabalho de artífice da imagem suscita no artista plástico, necessariamente, novas formas de ver e de reconfigurar o mundo (ficcional, neste caso), acrescentando e ampliando pormenores, focando aspetos que provavelmente passariam despercebidos ao leitor comum. Porém, como qualquer leitor comum, o artista plástico possui uma (relativa) liberdade interpretativa que lhe permite apropriar-se da história que é convidado a ilustrar, interpretandoa e recontando-a através da sua expressão artística. No fundo, esse trabalho de (re)criação permite ao ilustrador "alargar a dimensão imaginante do texto verbal, compondo um percurso que evita a redundância e oferece à sensibilidade do leitor um olhar outro" (Veloso, 2005, p. 9).

Dessa forma, entendemos que texto e imagem se devem articular harmonicamente num livro para crianças, de modo a permitir ao público (pré)leitor apreender mais facilmente os sentidos explícitos e implícitos que a obra transmite ou apenas insinua. A obra de arte, 


\section{pro.posıções}

ISSN 1980-6248

precisamente por permitir várias leituras e interpretações, fomenta as capacidades cognitivas, percetivas, imaginativas e sensoriais da criança, o que se revelará decisivo na sua educação estética e literária.

\section{Literatura para a infância e desenvolvimento infantil}

Psicólogos, pedagogos, professores e outros agentes educativos reconhecem hoje que o contacto precoce e sistemático da criança com o livro é de extrema relevância para o desenvolvimento cognitivo, psicológico, socioafetivo e emocional do ser em crescimento. $\mathrm{Na}$ verdade, desde os anos 90 do século XX, os estudos nesta área têm vindo a demonstrar que o convívio frequente da criança com os livros de qualidade, e em particular com a literatura para a infância, não só cria laços afetivos com o ato de (ouvir) ler, como proporciona um alargamento da capacidade imaginativa e simbólica da criança, alimenta o seu intelecto, favorece a apreensão das estruturas narrativas e das convenções literárias, alarga o seu capital lexical, cria o gosto pela leitura (do texto e da imagem) e estimula o desenvolvimento da sua sensibilidade artística (Cerrillo, 2001; Cervera, 1992; Colomer, 1994).

De facto, a literatura para a infância atual constitui um território especialmente propício à fruição estética, até porque a sua finalidade primeira, como a de qualquer obra de arte, é "promover na criança o gosto pela beleza da palavra, o deleite pela criação de mundos de ficção" (Mesquita, 1999, p.3), mas também nos parece inquestionável que, devido às suas inúmeras potencialidades - cognitivas, linguístico-lexicais, morfossintáticas, estilísticas, entre outras -, a literatura para a infância é crucial

para o desenvolvimento global infantil, nomeadamente pela capacidade de assim se permitir alargar a imaginação da criança (pré)leitora, de desenvolver o seu pensamento divergente e a sua sensibilidade artística e, naturalmente, a sua competência leitora, ou seja, a sua capacidade de extrair sentidos plurais dos textos que lê ou ouve ler e alargar o seu modo de ver o mundo e de nele se integrar, reconhecendo-se assim à criança o seu papel dinâmico, ativo e interpretativo no que respeita ao ato de ler (ou ouvir ler) desde tenra idade. (Ferreira, 2013, p. 32)

Sendo a criança - como nos demonstrou a Psicologia do Desenvolvimento, nomeadamente através dos estudos de Piaget, Vigotsky e seus seguidores - um ser em crescimento, com uma (ainda) curta experiência de vida, é natural que não consiga aceder na plenitude a todos os sentidos veiculados pelo texto literário e pelas ilustrações artísticas que nele 


\section{pro-posıções}

se fundem para o complementar, interpretando-o e recriando-o. Porém, tais limitações percetivas, linguísticas, culturais e, obviamente, vivenciais -, decorrem naturalmente da fase de desenvolvimento em que a criança se encontra, o que não significa que se deva por isso infantilizar o discurso, reduzi-lo ao essencial, destituí-lo de qualidade literária, da mesma forma que não se deve apostar em ilustrações desprovidas de uma dimensão imaginante e polissémica, menosprezando dessa forma a inteligência e a sensibilidade da criança.

Pelo contrário, as obras destinadas ao potencial recetor infantil devem possuir uma riqueza e uma densidade semântica que exijam ao leitor um esforço interpretativo que lhe permitirá elevar os seus níveis de compreensão leitora e alargar a sua capacidade cognitiva, linguística e simbólica, na medida em que

a abordagem literária dos temas, consubstanciada na utilização de técnicas e procedimentos retórico-discursivos adequados ao nível etário e de desenvolvimento cognitivo e psico-emotivo do leitor infantil ou juvenil, é feita ... através de uma linguagem ambivalente e plurissignificativa, onde o dito e o não dito concorrem para um mesmo fim - a educação literária do jovem leitor. (Mergulhão, 2008, p. 34)

O contacto com a literatura para a infância permite assim não só criar o prazer estético e lúdico, o desenvolvimento da imaginação e da sensibilidade, como também captar sentidos implicados nos textos (e nas imagens) de forma a desenvolver a compreensão leitora. Não é suposto que, no jardim de infância, a abordagem ao livro vise explorar de forma pormenorizada as convenções próprias do texto literário (ou do texto visual), porque tal estratégia, quando sistemática e exaustiva, levaria a uma natural rejeição por parte da criança, que, à partida, veria nesses momentos de pós-leitura uma tarefa escolarizada e maçadora. No entanto, é inegável que a criança necessita da ajuda do adulto-mediador para se embrenhar nas estruturas linguísticas e simbólicas do texto literário, e assim iniciar a sua educação literária o mais precocemente possível.

Mesmo no caso dos pré-leitores, naturalmente conduzidos pelo adulto-mediador, as obras literárias destinadas ao potencial recetor infantil permitem "ampliar a capacidade interpretativa da criança, desafiando-a a desocultar sentidos e aventurar-se pelos caminhos do inefável, pessoalizando dessa forma a significação textual com a sua particular forma de ver e de sentir" (Mergulhão, 2011, p.1), acrescentando ainda a autora que 


\section{pro.posições}

a participação activa do leitor infantil neste dinâmico processo hermenêutico de interpretação do lido afigura-se imprescindível para estabelecer os alicerces de uma verdadeira competência leitora ..., porque a criança, nomeadamente através do desenvolvimento da sua capacidade inferencial, aprende a desautomatizar o seu olhar e a percorrer os trilhos que lhe são propostos ou insinuados, quer pelo texto quer pelas ilustrações. (Mergulhão, 2011, p.2)

$\mathrm{Na}$ verdade, mais do que destinatária passiva de uma obra que lhe é particularmente destinada, a criança é uma recetora ativa, que não se limita a decifrar o texto e as imagens que o complementam, mas que interage e atua sobre a obra, produzindo novos significados e preenchendo os vazios discursivos propositadamente deixados em aberto. Efetivamente, como é sustentado pelas investigações que têm sido realizadas desde os finais do século XX neste domínio, "no texto literário, se é que é literário, sempre existe uma parte 'não escrita', isto é, espaços por resolver que estimulam a ação do leitor" (Mesquita, 1999, p.7). Assim se compreende que

o contacto precoce e sistemático da criança com o livro de qualidade é uma mais-valia no seu processo formativo a vários níveis. Para além de surpreender e de provocar deslumbramento, de alargar o capital lexical e estimular a sua compreensão leitora, a literatura infantil permite à criança, pela mediação da ficcionalidade e da construção de mundos possíveis, alternativos ao real, a compreensão da realidade que a rodeia e um posicionamento crítico e judicativo face a essa mesma realidade e face aos seus próprios modos de agir e de pensar. Através do livro, a criança vai realizando avanços e conquistas no processo de (auto) conhecimento, de conexão e de inserção no mundo e na sociedade, mas também no seu universo emocional e cognitivo. (Ferreira, 2013, p.36)

Ou seja, apesar de a obra literária visar sobretudo a fruição estética e o prazer de ler/ouvir ler, parece inquestionável que ela pode contribuir decisivamente para o desenvolvimento global da criança, a vários níveis (embora saibamos que não será assim com todas as crianças, de igual forma e ao mesmo tempo):

- Em termos cognitivos, por permitir à criança alargar a capacidade de entender o mundo que a rodeia, ao confrontar-se com novas formas de representação do real que lhe são fornecidas pelos mundos possíveis da ficção; por desenvolver o seu raciocínio e os esquemas mentais que o enformam, percebendo, por exemplo, a estrutura narrativa e as sequências temporais e espaciais em que ela se desenrola; por permitir relacionar o vivido e o por viver, o lido e o que nele se inscreve em termos de representação da condição humana; por permitir organizar o seu pensamento e estimular o pensamento divergente, o espírito crítico e reflexivo. 


\section{pro.p̣osições}

- Em termos linguísticos (lexicais, morfossintáticos e semânticos) e literários, por permitir alargar o capital lexical e morfossintático da criança e fazê-la entender os duplos sentidos que as palavras possuem no domínio do literário, relacionando o uso figurativo das palavras com o uso primário da língua e o sentido denotativo que as palavras possuem no mundo real; por permitir desenvolver a linguagem oral da criança, contribuindo para ampliar as suas estruturas frásicas em contextos diversificados e pragmáticos de comunicação (entre crianças e com os adultos); por facilitar a compreensão de analogias, comparações, metáforas e outros procedimentos literários que auxiliam a criança a desenvolver a sua capacidade interpretativa e a sua competência leitora.

- Em termos psicológicos, por permitir à criança projetar-se nas personagens de ficção e nos seus modos de agir, num processo psicológico de transferência que a ajudará a consolidar a sua identidade pelo confronto com o outro; por ajudar a criança a apaziguar alguns receios e angústias que se lhe colocam nesta fase do seu desenvolvimento, na medida em que ela encontra retratadas nos livros, frequentes vezes, situações e inquietações com as quais se identifica, mesmo que os livros não lhe forneçam as respostas que procura (pelo menos explicitamente).

- Em termos sociais e morais, por lhe permitir distinguir o bem e o mal, adquirindo valores sociais e morais que serão determinantes na formação do seu mundo interior; por lhe permitir colocar-se simbolicamente no lugar do outro e entender melhor as suas experiências de vida, os seus problemas, as suas contingências; por permitir relacionar-se melhor com as outras crianças e com os adultos, aceitando e respeitando as diferenças, numa clara afirmação do espírito de cidadania.

Pelo exposto se compreende que a literatura para a infância, sendo um sistema intersemiótico de extrema importância no desenvolvimento da sensibilidade artística e da fruição, pode igualmente ser encarada como um território fértil e multifacetado para o desenvolvimento global da criança e para a aquisição, natural e não forçada, de competências diversificadas em vários domínios. Com efeito, a diversidade de temas e de abordagens que a literatura para a infância declina permite à criança alargar as suas perspetivas de vida, os seus pontos de vista, os seus modos de ver o mundo e de nele se inserir. Permite igualmente ampliar 


\section{pro.posıções}

ISSN 1980-6248

os seus interesses de leitura e descobrir novos caminhos que a conduzirão, muito provavelmente, a um melhor conhecimento (e a uma melhor aceitação) de si e dos outros.

Porém, e para que tal aconteça, julgamos absolutamente fulcral que exista uma relação de cumplicidade e de afeto que a criança deverá estabelecer com o livro - com o que ela escolher, com aquele que lhe provocar um impacto emocional que estimule a sua adesão espontânea ao objeto amado, mas também com aquele, pelo menos assim se deseja, que o adulto-mediador, com toda a sua sensibilidade, lhe dará a conhecer.

Sabemos que a relação que a criança estabelece com o livro é, em primeiro lugar, uma relação genuinamente apaixonada. Efetivamente, quando este não a deixa indiferente, quando toca o seu lado mais sensível e emotivo, a criança deslumbra-se, comove-se, enraivece-se, ri ou chora, assusta-se, reagindo emocionalmente à leitura do livro, nele direta ou indiretamente se projetando. Essa reação emotiva será inevitavelmente mais intensa quanto mais o livro a inquietar, a desafiar, a implicar afetivamente na leitura, e isso acontece, sobretudo, quando os livros são plurissignificativos e deixam margem para o preenchimento das intencionais lacunas discursivas que o potencial leitor infantil conseguirá completar.

Sendo inegável a importância dos livros no desenvolvimento global da criança, as investigações que têm vindo a ser realizadas desde as duas últimas décadas do século XX atribuem a esse sistema literário um lugar incontornável na relação afetiva da criança com o livro de qualidade estético-literária, relação essa que deverá iniciar-se o mais cedo possível. A este propósito, afirma Veloso (2005):

Sempre defendi que o livro deve estar ao lado do biberão. Se o adulto ler histórias ao bebé nos primeiros meses de vida, o sistema neurológico do pequeno ser é impressionado favoravelmente, permitindo que os estímulos linguísticos, carregados de grande afectividade, promovam inúmeras sinapses e desencadeiem múltiplas reacções de adaptação ao mundo envolvente. ... Os banhos linguísticos que o acto de contar histórias proporciona representam um factor de grande importância no desenvolvimento da criança; as competências que esta vai adquirindo permitem-lhe avanços significativos na compreensão do mundo e nas aprendizagens emocionais e cognitivas. (p.5)

A literatura para a infância pode, neste contexto, contribuir para o desenvolvimento emocional da criança, apresentando-lhe situações de tensão e conflito em que as personagens se envolvem e com as quais se debatem interiormente de forma emotiva (pela manifestação da tristeza, da raiva, do ciúme, da inveja, do medo), ou exteriorizando tais emoções em face do 


\section{pro.posições}

ISSN 1980-6248

outro. Ou seja, a criança leitora compreende, dessa forma, que é natural que ela própria as sinta em diferentes momentos da sua vida, não devendo por isso culpabilizar-se por senti-las.

No fundo, procura-se, nesses casos, desmistificar e apaziguar os medos e os traumas que os mais novos possam eventualmente possuir, quase sempre apresentando, de forma subtil e implícita, caminhos possíveis para ultrapassar tudo aquilo que os angustia. Desse modo, como defende Ferreira (2013), as histórias

permitem à criança a entrada no mundo ficcional mas também uma compreensão do mundo circundante, na medida em que é confrontada com situações vividas pelas personagens, assim como com os seus diversos modos de atuação e com a forma como estes se refletem tanto nas próprias personagens, como naqueles que as rodeiam. Ao projetar-se nessas personagens, que vivem por vezes dramas pessoais ou enfrentam situações de dúvida ou conflito, a criança aprende por si, ou através da mediação do adulto, que a vida nem sempre é linear e que os problemas com que se deparam as personagens (e porventura ela própria) poderão ser resolvidos, o que apazigua medos e inseguranças próprios do estádio de desenvolvimento em que as crianças em idade pré-escolar se encontram. (p. 36)

$\mathrm{Na}$ verdade, projetando-se na história, a criança percebe, por exemplo, que a perda é inevitável (tal como a dor que deriva dessa perda), que ter ciúme ou medo faz parte da condição humana, e que todas as pessoas os têm, mas o que é realmente importante é encontrar a melhor forma para lidar com o que nos entristece, magoa ou enfurece e assim encontrar um sentido para a vida. A este respeito, diz-nos Bruno Bettelheim (1985):

Para que uma história possa prender verdadeiramente a atenção de uma criança, é preciso que ela distraia e desperte a sua curiosidade. Mas, para enriquecer a sua vida, ela tem de estimular a sua imaginação; tem de ajudá-la a desenvolver o seu intelecto e esclarecer as suas emoções; tem de estar sintonizada com as suas angústias e as suas aspirações; tem de reconhecer plenamente as suas dificuldades e, ao mesmo tempo, sugerirsoluções para os problemas que a perturbam. (p.11)

Apesar desse enfoque particular nos temas que vão ao encontro das inquietações e dos dilemas do ser em crescimento, a literatura para a infância dá igualmente relevância ao amor, à amizade, ao bem-estar, apresentando situações em que as personagens assumem o afeto pelo outro, exteriorizando assim emoções como a alegria ou a ternura e assumindo atitudes e comportamentos de abnegação e altruísmo. Tais histórias contribuem para tranquilizar a criança e para lhe demonstrar que, apesar de todas as angústias e dificuldades, de todos os problemas que possam existir, há sempre alguém por perto, para nos aconchegar emocionalmente. Ao ler tais histórias, ela, muito provavelmente, sentir-se-á mais segura do ponto de vista emotivo e conseguirá manifestar os seus afetos sem constrangimentos ou receio de ser rejeitada. $\mathrm{Na}$ 


\section{pro.posıções}

ISSN 1980-6248

opinião de Santos (2013), “estas [narrativas] são fonte de experiências ..., funcionando como um laboratório de experimentação de sentimentos e emoções, que permitem uma memória emocional dos acontecimentos estruturadora da relação da criança com o mundo" (p.12).

Assim se compreende que o contacto precoce com a literatura para a infância, para além de todos os benefícios que acarreta, como referimos anteriormente, é de extrema importância para dar segurança e bem-estar emocional à criança. Para além de serem marcadas por valores estético-literários, socioculturais, morais e cívicos, as narrativas literárias são também um espaço de descoberta emocional que permite à criança organizar e vivenciar múltiplas emoções, promovendo o seu desenvolvimento, a sua maturidade e a sua capacidade relacional.

Contudo, e devido às naturais limitações da criança pré-leitora em termos de vivências e experiências de vida, a intervenção do adulto-mediador nesse processo de desocultação dos sentidos implícitos na literatura para a infância afigura-se imprescindível para auxiliar a criança a compreender, pela via da projeção identificativa, as suas próprias emoções, os seus sentimentos, as suas inquietações e os seus problemas de ordem existencial e afetiva.

\section{Considerações finais}

A criança precisa, acima de tudo, de se sentir segura e emocionalmente estável para se sentir motivada para aprender a aprender, para se envolver em aprendizagens significativas num ambiente educativo que valorize as suas opiniões e que a estimule em termos cognitivos, psicoemotivos e relacionais. A sua plena integração no grupo, a construção da sua autoestima, o respeito pelas opiniões alheias, a aceitação das diferenças constituem os alicerces de uma educação para a cidadania que se deseja vir a manter-se ao longo da vida. Nesse sentido, e não sendo a única via para atingir esse fim, a literatura para a infância é um precioso auxiliar do educador de infância no desenvolvimento global da criança e, em particular, ao nível do seu desenvolvimento emocional.

O adulto-mediador deverá incentivar a relação da criança com o livro, por vários motivos determinantes na consolidação da personalidade infantil e da criação de projetos de leitor que provavelmente se revelarão essenciais na formação literária desses pequenos pré-leitores, mas também porque este é um terreno fértil para despoletar situações comunicativas que permitam a reflexão das crianças sobre atitudes e emoções com as quais, ao longo da vida, se irão deparar. 


\section{pro-posıções}

ISSN 1980-6248

Julgamos que ao educador de infância compete essa missão de preparar as crianças para a vida e, por isso, a par das aprendizagens inerentes às diversas áreas de conteúdo, a relação da criança consigo própria, com as suas angústias e os seus dilemas, com as suas alegrias e as suas tristezas, as suas angústias e as suas revoltas, e, paralelamente, a relação com o outro, são aspetos que merecem toda atenção de pais, educadores e outros agentes educativos que querem, acima de tudo, proporcionar às crianças um desenvolvimento global e harmonioso, num clima de bemestar que se revelará crucial no seu futuro.

\section{Referências Bbliográficas}

Azevedo, F. (2003). Estudos literários para a infância e fomento da competência literácita. In G. S. de Carvalho [et al.] (Org), Saberes e práticas na formação de professores e educadores (pp. 125-132). Braga: Instituto de Estudos da Criança da Universidade do Minho. Acedido a 13 de novembro de 2013, em http://repositorium.sdum.uminho.pt/handle/1822/2857.

Bettelheim, B. (1985). Psicanálise dos contos de fadas. Venda Nova: Bertrand.

Cerrillo, P. (2001). Lo literario y lo infantil: concepto y caracterización de la literatura infantil. In P. Cerrillo, \& J. G. Padrino (Orgs.), La literatura infantil en el siglo XXI (pp. 79-94). Cuenca: Ediciones de la Univ. Castillla-La Mancha.

Cervera, J. (1992). Teoria de la literatura infantil. Bilbao: U. Desto/Ediciones Mensajero.

Colomer, T. (1994). El lector de la etapa infantil (0-6 años). Alacena, 21, 18-24.

Ferreira, A. (2013). Identidade e alteridade: a literatura infantil como oportunidade de abordagem aos valores na educação pré-escolar. Portalegre: IPP.

Hunt, P. (1994). Criticism, theory \& children's literature. Oxford: Blackwell.

Lopes, M. (2012). O interpretante emocional na interação das linguagens visual e verbal em Chapeuzinho Amarelo, de Chico Buarque e Ziraldo. In R. Araújo., \& W. Oliveira (Orgs.), Literatura infantojuvenil: diabruras, imaginação e deleite (pp. 109-122). Vila Velha: Opção.

Maia, G. (2002). O visível, o legível e o invisível. Malasartes - Cadernos de Literatura para a Infância e a Juventude, 10, 3-8. Porto: Campo das Letras.

Marchão, A. (2013). O lugar dos livros no jardim de infância. Aprender, 33, 25-34. 


\section{pro-posıções}

ISSN 1980-6248

Mata, L. (2008). A descoberta da escrita - textos de apoio para educadores de infância. Lisboa: Ministério da Educação - Direção Geral de Inovação e de Desenvolvimento Curricular.

Mendes, T. (2013). Amor como em casa: o lugar da família e dos afetos na literatura infantil contemporânea. Aprender, 33, 35-40.

Mergulhão, T. (2008). Vozes e silêncio: a poética do (des)encontro na literatura para jovens. Lisboa: FLUL. Acedido a 25 de outubro de 2013, em http://repositorio.ul.pt/handle/10451/582.

Mergulhão, T. (2011, junho). Literatura infantil e a técnica do voo. Profforma, 03, 1-2.

Mesquita, A. (1999). A estética da recep̧̧ão na literatura infantil (Série Ensaio). Vila Real: UTAD.

Nikolajeva, M., \& Scott, C. (2001). How picturebooks work. London: Garland.

Nodelman, P. (1988). Words about pictures: The narrative art of children's picturebooks. Georgia: University of Georgia Press.

Padrino, J. (2001). La investigación de la Literatura Infantil en España: en busca de una identidad científica. In P. Cerrillo, \& J. Padrino (Orgs.), La literatura infantil en el siglo XXI (pp. 1326). Cuenca: Ediciones de la Univ. Castillla-La Mancha.

Santos, M. (2013). Do sentir e do significar - uma leitura do papel das narrativas para o desenvolvimento emocional da criança. Aprender, 33, 11-17.

Silva, S. (2003). Quando as palavras e as ilustrações andam de mãos dadas: aspectos do álbum narrativo para a infância. Casa da Leitura. Acedido a 10 de outubro de 2013, em http://195.23.38.178/casadaleitura/portalbeta/bo/documentos/ot_palav_ilustra_a_C.pdf

Sipe, L. (2007). A unique visual and literary art form: Recent research on picturebooks. Language Arts, 83(3), 273-280. Acedido a 12 de outubro de 2013, em http://repository.upenn.edu/gse_pubs/32.

Soares, A. (1994). A função da ilustração na literatura infanto-juvenil. Mathésis, 3. Viseu: Universidade Católica Portuguesa. Acedido a 1 de novembro de 2013, em http://hdl.handle.net/10316.2/24009.

Veloso, R. (2005). Não-receita para escolher um bom livro. Casa da Leitura. Acedido a 14 de agosto de 2013, em http://195.23.38.178/casadaleitura/portalbeta/bo/portal.pl?pag=abz_ot_detalhe\&id=24 .

Submetido à avaliação em 25 de abril de 2016; aceito para publicação em 02 de agosto de 2016. 